\title{
NEWLY DISCOVERED RELIC POPULATION OF RUBUS CHAMAEMORUS L. IN THE WESTERN CARPATHIANS
}

\author{
ANNA KOCZUR \\ Institute of Nature Conservation, Polish Academy of Sciences \\ Mickiewicza 33, 31-120 Kraków, Poland \\ e-mail: koczur@iop.krakow.pl
}

(Received: May 28, 2003. Accepted: February 13, 2004)

\begin{abstract}
In the territory of Poland, Rubus chamaemorus is a rare glacial relict. Its localities known to date were in the northern part of the country and in the Sudeten Mountains. In 2002, a new locality of this species was discovered in the Orawa-Nowy Targ basin in the Carpathians. It is the southernmost locality in the European distribution area of this species. Rubus chamaemorus grows there on a raised bog in communities of the Oxycocco-Sphagnetea class. The spatial structure of the population depends on microhabitats reflecting the hummock-hollow structure of the peatbog.
\end{abstract}

KEY WORDS: Rubus chamaemorus, relic species, Western Carpathians, Orawa-Nowy Targ basin, raised bog.

\section{INTRODUCTION}

Cloudberry (Rubus chamaemorus L.) is an endangered (EN) species in Poland. It is one of the rarest elements of the Polish flora, entered into the national red list of endangered and vulnerable species (Zarzycki, Szeląg 1992), and into the Polish Red Book of Plants (Kaźmierczakowa, Zarzycki 2001). In Poland, this species is a glacial relic (Pawłowska 1972). The objective of this paper was to describe the newly discovered locality of Rubus chamaemorus and to study the conditions of development of the population on this southernmost locality of the species in Europe.

\section{MATERIAL AND METHODS}

The distribution of this species in Europe is given after Hultén and Fries (1986), the distribution in Poland - after literature data. The edaphic conditions were characterised on the basis of analysis of a peat sample collected on a small hillock (henceforth termed as transitional conditions) up to ca. $40 \mathrm{~cm}$ deep. The acidity of peat $(\mathrm{pH}$ in $\mathrm{H}_{2} \mathrm{O}$ and $\mathrm{KCl}$ ) was measured by means of the potentiometric method, and loss at ignition was determined at $550^{\circ} \mathrm{C}$. The species composition of peat sample and proportions of various genera and species in the sample was determined by microscopic analysis of plant remains.

Two relevés (phytosociological records), using the Braun-Blanquet method, were taken in the site occupied by the newly discovered population. Because the patch with cloudberry showed a typical structure of hummocks and hollows and hence was not homogenous in both phytosociological and habitat aspects, detailed analyses were carried out on 15 randomly chosen $40 \times 40 \mathrm{~cm}$ plots. This size of sample plots allowed to analyse the possibly largest homogenous patches. The sample plots were placed in these patches where the phytosociological records were taken, in three types of microhabitats, five plots within each type: (1) within the tallest hummocks, (2) within small hillocks and edges of hummocks (transitional conditions) and (3) in depressions between hummocks (there are no typical hollows occupied by communities of the Rhynchosporion albae alliance).

In order to characterize the structure and habitat preferences of this Carpathian population, the following factors were determined: number of shoots above the ground, number of leaves on each shoot, length and width of leaves. All species occurring in squares were recorded and their respective percentage coverage assessed.

The average densities of cloudberry shoots in squares were determined in various microhabitats. A basic statistical analysis of leaf length and width in Rubus chamaemorus consisted in checking the distribution of variables against normal distribution, determination of median and finding minimum and maximum values. The differences in leaf size in individuals from different microhabitas were determined by means of the Kruskal-Wallis test. 


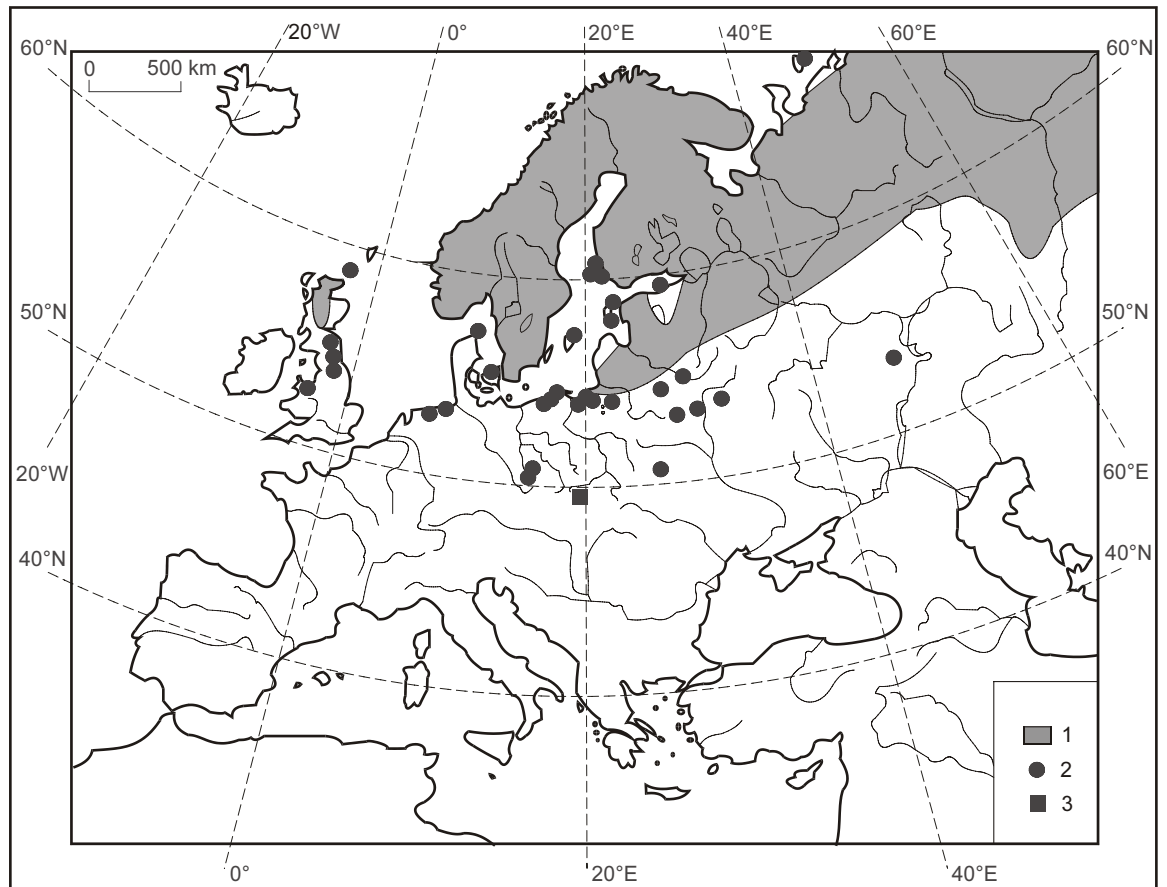

Fig. 1. Distribution of Rubus chamaemorus in Europe (after Hultén and Fries 1986). 1 continuous range; 2 - single locality or group of localities situated close one to another; $3-$ newly discovered locality.

\section{DISTRIBUTION}

Rubus chamaemorus is an arctic-boreal species of circumboreal distribution. According to Gostyńska-Jakuszewska, Lekavičius (1994), the southern limit of its distribution in Europe runs along the $50^{\circ}$ of northern geographical latitude. In Europe, its solid range includes the northern part of Great Britain, Scandinavia, eastern part of the Baltic lake district and the northern part of East-European lowlands (Fig. 1). The southern limit of distribution in Poland follows the Braniewo-Morąg-Gębin on the Pregoła line in the north-eastern part of the country (Czubiński 1950). Beyond this line cloudberry occurs only on scattered localities. In

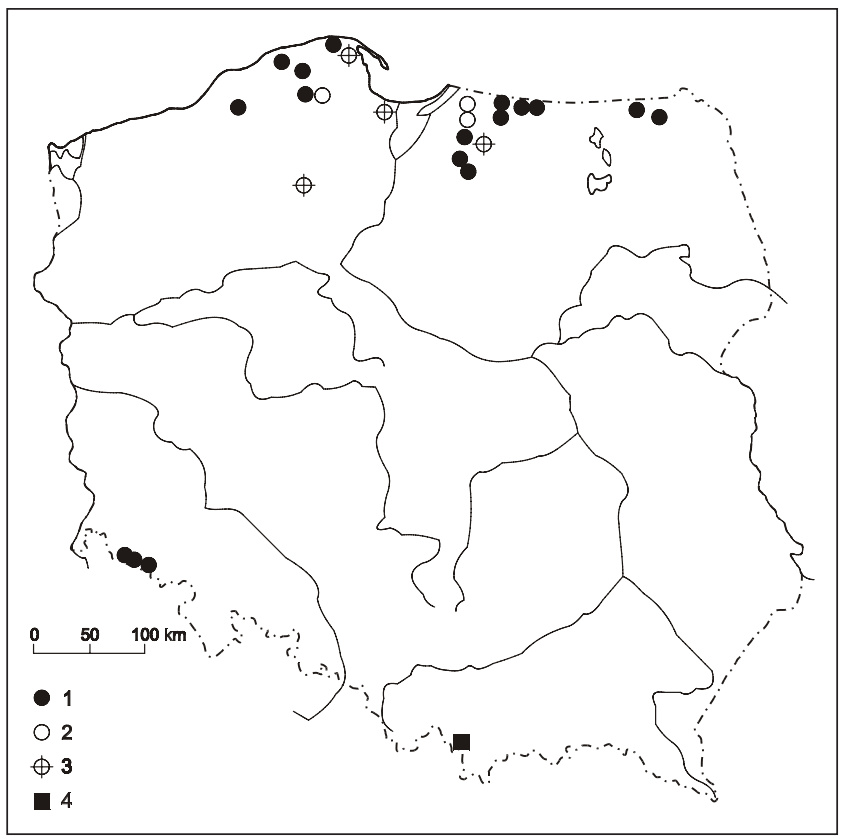

Fig. 2. Distribution of Rubus chamaemorus in Poland (after Kruszelnicki, Fabiszewski 2001). 1 - locality confirmed after 1980; 2 - localities not confirmed after 1980; 3 - historical localities; 4 - newly discovered locality.
Poland, cloudberry occurs in its northern part in Warmia and Masuria regions (currently 9 localities) and in Pomerania (5 localities) (Kruszelnicki, Fabiszewski 2001) and in the southern part of its range - in the Karkonosze Mountains - 3 localities (Wojtuń, Matuła 2000; Schube 1903; Fabiszewski, Pałczyński 1970) (Fig. 2). Localities of this species can be found also over the border, on the Czech part of the Karkonosze range (Procházka, Štursa 1999).

The localities in the Karkonosze Mountains were regarded as the only ones in mountainous areas of Central Europe (Pawłowski 1972). Rubus chamaemorus was reported as being one of the few glacial relicts which occurs in the $\mathrm{Su}$ deten Mts, not appearing in the Carpathians (Pawłowski 1972).

In 2002, in the course of field studies, a new locality of this plant was discovered. It is located within Puścizna Wielka peatbog in Orawa-Nowy Targ basin in the Western Carpathians (ATPOL - DG38). To date, it is the only place in the Carpathians and the southernmost of the existing European localities of this species (at $49^{\circ} 27^{\prime} \mathrm{N}$ geographical latitude, while the latitudes of the Karkonosze localities groups around $50^{\circ} 44^{\prime} \mathrm{N}$ ).

\section{Habitats}

Cloudberry always grows on peat substrate, on extremely oligotrophic, strongly acidic peats with $\mathrm{pH}$ below 4 (Zarzycki 2002), in raised bogs and coniferous bog forests. The Carpathian population occurs in a raised bog of Baltic type, on a thick layer of peatmoss substrate with $\mathrm{pH}$ in water 3.7 and in $\mathrm{KCl}-2.4$. The upper layer of peat (up to the depth of $40 \mathrm{~cm}$ ) is formed by several species of peatmosses where Sphagnum rubellum, S. medium and S. fuscum predominate. The combined mass of peatmosses accounts for ca. $75 \%$ of the total mass of peat. Apart from these, there are also significant proportions of remains of Oxycoccus and other Ericaceae (ca. 20\%), whereas the proportion of Eriophorum vaginatum is low (up to $3 \%$ at some places). The degree of decomposition is low. The loss on ignition is 
TABLE 1. Floristic composition (A) and spatial diversity (B) of the patch with Rubus chamaemorus viewed against the data on density of shoots.

\begin{tabular}{|c|c|c|c|c|c|c|c|c|c|c|c|c|c|c|c|c|c|}
\hline \multirow{3}{*}{ No. of relevé/square } & \multirow{2}{*}{\multicolumn{2}{|c|}{ A }} & \multirow{2}{*}{\multicolumn{15}{|c|}{ B }} \\
\hline & & & & & & & & & & & & & & & & & \\
\hline & 611 & 612 & $\mathrm{H} 4$ & H5 & $\mathrm{H} 2$ & $\mathrm{H} 1$ & $\mathrm{H} 3$ & $\mathrm{~T} 4$ & $\mathrm{~T} 2$ & $\mathrm{~T} 3$ & $\mathrm{~T} 1$ & T5 & D4 & D1 & D3 & D2 & D5 \\
\hline Cover of tree layer in $\%$ & 1 & - & - & - & - & - & - & - & - & - & - & - & - & - & - & - & - \\
\hline Cover of shrub layer in $\%$ & 10 & 30 & - & - & - & - & - & - & - & - & 50 & 80 & - & - & - & - & - \\
\hline Cover of herb layer in $\%$ & 80 & 70 & 50 & 45 & 70 & 95 & 40 & 50 & 50 & 65 & 60 & 90 & 20 & 30 & 35 & 15 & 15 \\
\hline Cover of bryophytes layer in \% & 100 & 100 & 100 & 100 & 100 & 100 & 100 & 95 & 100 & 100 & 100 & 80 & 100 & 100 & 100 & 100 & 100 \\
\hline Height of trees/shrubs in $\mathrm{m}$ & 2 & 1.5 & - & - & - & - & - & - & - & - & 0.5 & 1 & - & - & - & - & - \\
\hline Area of sample plot in $\mathrm{m}^{2}$ & 100 & 100 & 0.16 & 0.16 & 0.16 & 0.16 & 0.16 & 0.16 & 0.16 & 0.16 & 0.16 & 0.16 & 0.16 & 0.16 & 0.16 & 0.16 & 0.16 \\
\hline \multicolumn{18}{|c|}{ Ch. Oxycocco-Empetrion (Sphagnetum fusci) } \\
\hline Empetrum nigrum & 2 & 2 & 40 & 25 & 30 & 50 & 15 & 4 & 15 & 20 & 15 & 25 & 7 & 0.1 & 10 & 3 & 1 \\
\hline Sphagnum fuscum (d) & 1 & 2 & 98 & 95 & 80 & 40 & 30 & 2 & 1 & . & . & . & . & . & . & . & . \\
\hline Oxycoccus microcarpus & 1 & 1 & 1 & 1 & . & 5 & . & . & 0.1 & . & . & . & . & . & . & . & . \\
\hline Rubus chamaemorus & 1 & 1 & 1 & 2 & 5 & 2 & 3 & 8 & 8 & 7 & 4 & 75 & 1 & 1 & 2 & 0.1 & 0.1 \\
\hline Ledum palustre & + & 1 & 3 & . & . & . & . & . & 5 & . & . & . & . & . & . & 3 & . \\
\hline \multicolumn{18}{|c|}{ Ch. Sphagnetalia magellanici (Sphagnetum magellanici) } \\
\hline Eriophorum vaginatum & 2 & 2 & 2 & 15 & 15 & 40 & 15 & 7 & 20 & 20 & 20 & 5 & 4 & 5 & 10 & 8 & 5 \\
\hline Oxycoccus palustris & 1 & 2 & 3 & 5 & 10 & 2 & 5 & 2 & 3 & 5 & 10 & 30 & 5 & 2 & 5 & 0.1 & 2 \\
\hline Andromeda polifolia & 1 & + & 1 & . & 18 & . & 1 & . & . & 1 & 12 & 1 & . & 5 & . & 1 & 3 \\
\hline Sphagnum magellanicum (d) & 3 & 2 & 0.5 & 2 & 10 & 20 & 40 & 5 & 40 & 70 & 50 & 2 & 1 & 25 & 4 & 10 & 5 \\
\hline Sphagnum rubellum (d) & 2 & 2 & 1 & 3 & 10 & 40 & 30 & 85 & 9 & 20 & 10 & . & 80 & 15 & 15 & 5 & 10 \\
\hline Polytrichum strictum $(\mathrm{d})$ & 1 & 1 & 0.5 & 1 & . & 0.1 & . & 2 & . & . & . & . & 2 & . & . & . & . \\
\hline Cephalozia connivens (d) & + & . & . & . & . & . & . & . & . & . & . & . & . & . & . & . & . \\
\hline \multicolumn{18}{|l|}{ Group of bog woods } \\
\hline Pinus $\mathrm{x}$ rhaetica $(\mathrm{b})$ & 1 & 3 & . & . & . & . & . & . & . & . & . & 80 & . & . & . & . & . \\
\hline Pinus mugo (b) & 1 & 1 & . & . & . & . & . & . & . & . & 50 & . & . & . & . & . & . \\
\hline Vaccinium uliginosum & + & + & . & . & . & . & . & . & . & . & . & . & . & . & . & . & . \\
\hline Pinus sylvestris (a) & 1 & . & . & . & . & . & . & . & . & 5 & . & . & . & . & . & . & . \\
\hline \multicolumn{18}{|l|}{ Ch. Oxycocco-Sphagnetea } \\
\hline Drosera rotundifolia & + & 1 & 0.1 & . & . & 1 & . & . & . & . & . & . & . & . & . & . & . \\
\hline Aulacomnium palustre (d) & + & + & . & . & . & . & . & . & . & . & . & . & . & . & 1 & . & . \\
\hline Sphagnum papillosum (d) & . & + & . & . & . & . & . & . & . & . & . & . & . & . & . & . & . \\
\hline \multicolumn{18}{|l|}{ Others } \\
\hline Calluna vulgaris & 2 & 1 & 1 & . & 0.1 & 1 & 2 & 30 & 5 & 15 & . & 15 & 5 & 20 & 8 & 4 & 5 \\
\hline Sphagnum recurvum $(\mathrm{d})$ & 3 & 2 & . & 0.1 & . & . & . & 5 & 50 & 10 & 40 & 80 & 19 & 60 & 80 & 85 & 85 \\
\hline Calypogeia integristipula (d) & + & . & . & . & . & . & . & . & . & . & . & . & . & . & . & . & . \\
\hline Cladonia sp. (d) & . & + & . & . & . & . & . & . & . & . & . & . & . & . & . & . & . \\
\hline Sphagnum cuspidatum (d) & + & . & . & . & . & . & . & . & . & . & . & . & . & . & . & . & . \\
\hline Number of shoots in a square & & & 4 & 9 & 17 & 7 & 10 & 23 & 12 & 30 & 15 & 55 & 2 & 3 & 3 & 2 & 6 \\
\hline Number of shoots with 1 leaf & & & 4 & 4 & 12 & 4 & 7 & 16 & 7 & 16 & 13 & 41 & 2 & 2 & 2 & 2 & 5 \\
\hline Number of shoots with 2 leaves & & & - & 4 & 5 & 2 & 2 & 7 & 5 & 12 & 2 & 9 & - & 1 & 1 & - & 1 \\
\hline Number of shoots with 3 leaves & & & - & 1 & - & 1 & 1 & - & - & 2 & - & 5 & - & - & - & - & - \\
\hline
\end{tabular}

A - relevés (phytosociological records) taken on 28.08.2002 on the bulge of Puścizna Wielka peatbog, elevation 655 m a.s.l., exposed to N, slope of the terrain $1^{\circ}$, quantity measures given in Braun-Blanquet scale.

$\mathrm{B}$ - floristic composition in $40 \times 40 \mathrm{~cm}$ squares chosen randomly in plot A; measurements taken on 7.09.2002, coverage by species given in per cent. H 1-5 - squares situated on hummocks; T 1-5 - squares situated at transitional elevations; D 1-5 - squares situated in depressions.

$85.75 \%$, which is rather low as for a typical raised bog. It is an indication of low mud deposition which could result from periodically occurring surface run-offs.

Rubus chamaemorus grows in the patch of hummockhollow mire which represents a mixture of two associations, possibly some regional variants of Sphagnetum fusci Luequ. and Sphagnetum magellanici boreale Jasn. The floristic composition of phytocoenose is shown in relevés, while the spatial differentiation of communities is illustrated by data from $0.16 \mathrm{~m}^{2}$ squares (Table 1 ).

\section{Characteristics of the population}

The described in this paper population of cloudberry covers ca. $150 \mathrm{~m}^{2}$. Only sterile individuals were found, of small size, usually growing one or two leaves just above the surface of peatmosses. The average density of shoots was $1-35$ per $1 \mathrm{~m}^{2}$, and only in several cases, under shrubs, it was many times higher (Table 1B). Depending on habitat, major differences in shoot density, number and size of leaves were observed (Figs 3, 4). Rubus chamaemorus definitely avoids depressions (the most humid habitats), its shoots are least numerous there (average of 3.2 per square), and leaves are tiny and dwarfed: the largest leaf found was merely $2.1 \mathrm{~cm}$ long and $3.3 \mathrm{~cm}$ wide. Only $19 \%$ of shoots grow two leaves. Cloudberry grows much better within hummocks, where shoots are more numerous (average of 9.4 per square), $28 \%$ bear two leaves, and shoots with three leaves appear (as much as 6\%). The plants growing on 


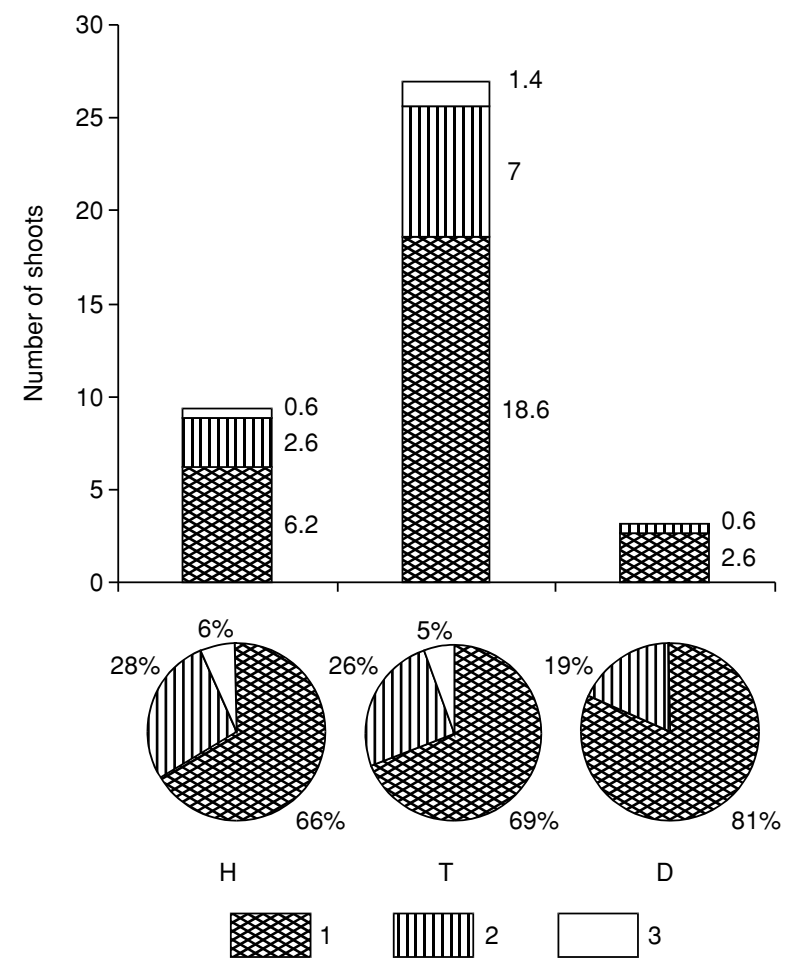

Fig. 3. Average number (A) and percentage proportion (B) of shoots having one (1), two (2) or three (3) leaves on sample plots $\left(0.16 \mathrm{~m}^{2}\right)$ in various types of microhabitats: $\mathrm{H}$ - highest hummock, $\mathrm{T}$ - transitional habitat, D - depression.

hummocks are also different in terms of leaf size (Fig. 4) the largest leaf was $3.7 \mathrm{~cm}$ long and $4.9 \mathrm{~cm}$ wide. The most favourable conditions prevail, however, on smaller hillocks and on edges of hummocks - in transitional conditions. This assessment is supported mainly by the highest shoot density (average 27 shots per square), and good condition of shoots in samples located here; actually the number of shoots with two or three leaves is comparable with samples from hummocks (slightly lower - Fig. 3). Although the differences in leaf size between samples from hummocks and transitional habitats are statistically insignificant (Table 2), but they differ markedly in maximum values (Fig. 4) i.e. some of the leaves reach greater size in transitional conditions. This is also favoured by the fact that shaded places

A

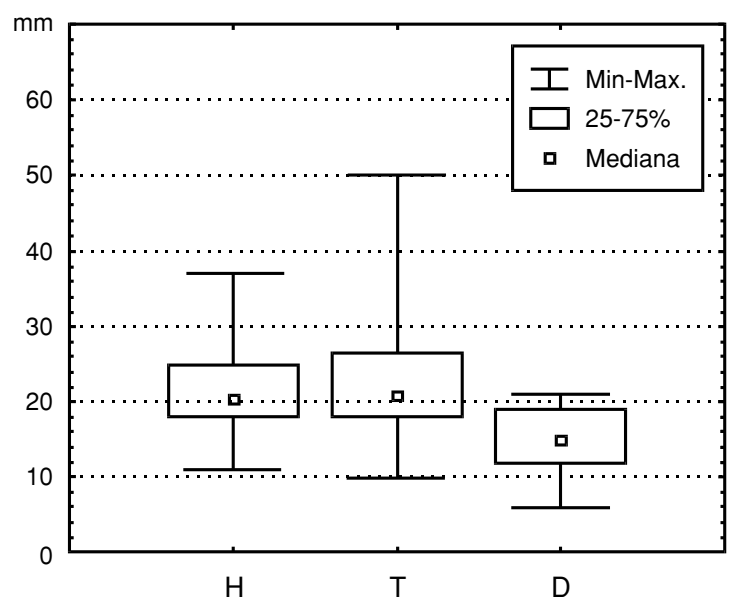

are most often found within these habitats where the layer of mosses is not that compact and the growth of peatmosses is significantly slower.

The conditions prevailing in the relic Carpathian locality are rather unfavourable for the development of cloudberry. It is manifested by lack of any generative individuals and by size and shape of shoots. The largest leaf from the described area (recorded in a sample taken from a shaded site on a transitional habitat) was merely $5 \mathrm{~cm}$ long and $6.2 \mathrm{~cm}$ wide. Thus, even the largest leaves do not reach the dimensions determined as average for an exemplary population in Western Pomerania (Janiewieckie bog), where the average leaf length and width are much larger depending on type of habitat (Król 1968).

\section{Relic nature of the locality}

The geographical location, enormous distance from other populations of the same species and also the habitat occupied by the population and its structure undoubtedly point at relic nature of the locality. It has all the features of relic localities (Kornaś 1958), such as:

- specific properties of the habitat - typical raised bog situated on a watershed with specific climate (dell surrounded by mountains with stagnant air),

- primeval properties of vegetation - communities of Oxycocco-Sphagnetea class on a thick layer of sphagnum peat,

- features of occurrence - numerous, but on a very limited surface,

- presence, within the same patch, of other species regarded as glacial relics (Czubiński 1950): Oxycoccus microcarpus, Ledum palustre, Empetrum nigrum.

Unfortunately, at present there are no direct palaeobotanical data available which would support the idea of Rubus chamaemorus surviving in Orawa-Nowy Targ basin since the glaciation period. To date, no remains of cloudberry plants have ever been found in the area and information on presence of the species in the Carpathians and their edges are very scarce. A single pollen grain of cloudberry was found only in a profile from Roztoki near Jasło in the Doły Jasielsko-Sanockie depressions (Harmata 1987). It dates back to the Allerød period, that is about the same time as peatbogs in the Orawa-Nowy Targ basin were formed (Obidowicz 1989). It

B

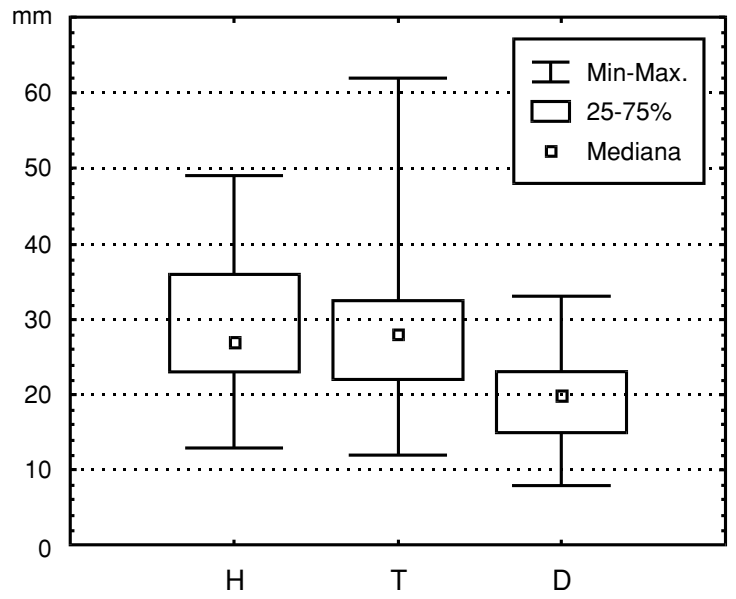

Fig. 4. Leaf dimensions in Rubus chamaemorus in particular types of microhabitat ( $\mathrm{H}$ - highest hummock, $\mathrm{T}$ - transitional habitat, D - depression); A - leaf length, B - leaf width. 
TABLE 2. Significance of differences between in Rubus chamaemorus leaf size in particular types of microhabitats (H - highest hummock, $\mathrm{T}-$ transitional habitat, D - depression) - results of Kruskal-Wallis test.

\begin{tabular}{|c|c|c|c|c|c|c|}
\hline \multirow{2}{*}{ Types of microhabitats compared } & \multicolumn{3}{|c|}{ Leaf length } & \multicolumn{3}{|c|}{ Leaf width } \\
\hline & $\mathrm{H}$ & df & $\mathrm{p}$ & $\mathrm{H}$ & df & $\mathrm{p}$ \\
\hline $\begin{array}{l}H-T \\
T-D \\
H-D\end{array}$ & $\begin{array}{c}0.66 \\
21.42 \\
16.55\end{array}$ & $\begin{array}{c}1.250 \\
1.203 \\
1.85\end{array}$ & $\begin{array}{l}0.4174 \\
0.0000 \\
0.0000\end{array}$ & $\begin{array}{c}1.25 \\
18.73 \\
19.82\end{array}$ & $\begin{array}{c}1.250 \\
1.203 \\
1.85\end{array}$ & $\begin{array}{l}0.2631 \\
0.0000 \\
0.0000\end{array}$ \\
\hline
\end{tabular}

cannot be excluded that the distribution of Rubus chamaemorus at that time included the northern part of the Carpathians, but this can be determined only by further palaeobotanical studies, principally in the Podhale and Orawa regions.

\section{Protection of the site}

In spite of many plans for the protection of the Orawsko-Nowotarskie raised bogs (Lubicz-Niezabitowski 1922; Obidowicz 1977; Denisiuk, ed. 1993), the Puścizna Wielka peatbog, as almost all other peatbogs, is not covered by any protection measures. Moreover, extraction of peat is pursued both by individual residents of nearby villages and on industrial scale. As the locality of cloudberry is located relatively close to the edge of the exploited edge of peatbog, a danger of total destruction of the locality is real. The only possibility to preserve this relic locality of cloudberry in the Carpathians is to stop peat extraction at least in the northern part of the peatbog, not yet exploited on industrial scale. It would be advisable to establish a reserve covering the surviving part of the peatbog with forest edge communities and the part of the coniferous bog forests adjoining the peatbog.

\section{LITERATURE CITED}

CZUBIŃSKI Z. 1950. Zagadnienia geobotaniczne Pomorza [Geobotanical problems in Pomerania]. Bad. Fizjogr. Pol. Zach. 2: 439-658. (in Polish with English summary)

DENISIUK Z. (ed.) 1993. Program rezerwatowej ochrony przyrody i krajobrazu polskich Karpat na tle aktualnej sieci obszarów chronionych [Programme of reserve protection of nature and landscape in the Polish Carpathians against a background of the actual net of protected areas]. Studia Naturae 39, pp. 101. (in Polish with English summary)

FABISZEWSKI J., PAŁCZYŃSKI A. 1970. Skalnica śnieżna i malina moroszka w Karkonoskim Parku Narodowym. Chrońmy Przyr. Ojcz. 26 (2): 28-31. (in Polish)

GOSTYŃSKA-JAKUSZEWSKA M., LEKAVIČIUS A. 1994. Selected boreal and subboreal species of vascular plants in the flora of Poland and Lithuania. Part II. Fragm. Flor. Geobot. 39 (1): 255-276.

HARMATA K. 1987. Late-glacial and Holocene history of vegetation at Roztoki and Tarnowiec near Jasło (Jasło-Sanok Depression). Acta Paleobot. 27 (1): 43-65.

HULTÉN E., FRIES M. 1986. Atlas of North European vascular plants north of the Tropic of Cancer. I-III. Koeltz Scientific Books, Köningstein.

KAŹMIERCZAKOWA R., ZARZYCKI K. (eds). 2001. Polska Czerwona Księga Roślin. Paprotniki i rośliny kwiatowe [Polish Red Data Book of Plants. Pteridophytes and flowering plants]. pp. 664. IB PAN \& IOP PAN, Kraków. (in Polish with English summary)

KORNAŚ J. 1958. Reliktowa kolonia roślin wysokogórskich w Małych Pieninach [A relic colony of alpine plants in the Małe Pieniny Mountains]. Ochr. Przyr. 25: 238-247. (in Polish with English summary)

KRÓL S. 1968. Zespoły roślinne i warunki siedliskowe rezerwatu Janiewickie Bagno koło Sławna na Pomorzu Zachodnim [Plant associations and habitat conditions of the nature reserve Janiewickie Bagno near Sławno in Western Pomerania]. Ochr. Przyr. 33: 139-165. (in Polish with English summary)

KRUSZELNICKI J., FABISZEWSKI J. 2001. Rubus chamaemorus L. Malina moroszka. In: R. Kaźmierczakowa, K. Zarzycki (eds). Polska Czerwona Księga Roślin. Paprotniki i rośliny kwiatowe [Polish Red Data Book of Plants. Pteridophytes and flowering plants]. pp. 192-194. IB PAN \& IOP PAN, Kraków. (in Polish with English summary)

LUBICZ-NIEZABITOWSKI E. 1922. Wysokie torfowiska Podhala i konieczność ich ochrony. Ochr. Przyr. 3: 26-34. (in Polish)

OBIDOWICZ A. 1977. Ochrona torfowisk Tatr i Podhala. Chrońmy Przyr. Ojcz. 33 (3): 50-55. (in Polish with English summary)

OBIDOWICZ A. 1989. Type region P-a: Inner West Carpathians - Nowy Targ Basin. Acta Paleobot. 29 (2): 11-15.

PAWŁOWSKA S. 1972. Charakterystyka statystyczna i elementy flory polskiej. In: W. Szafer, K. Zarzycki (eds). Szata roślinna Polski. I. pp. 129-206. PWN. Warszawa. (in Polish)

PAWŁOWSKI B. 1972. Szata roślinna gór polskich. In: W. Szafer, K. Zarzycki (eds). Szata roślinna Polski. II. pp. 189-252. PWN. Warszawa. (in Polish)

PROCHÁZKA F., ŠTURSA 1999. Rubus chamaemorus L. In: J. Čeřovský, V. Feráková, J. Holub, Š. Maglocký, F. Procházka (eds). Červená kniha ohrozených a vzácnych druhov rastlín a živočíchov SR a ČR 5. Vyššie rastliny. pp. 320. Príroda a.s., Bratislava. (in Slovakian)

SCHUBE T. 1903. Die Verbreitung der Gefäßpflanzen in Schlesien preußischen und österreichischen Anteils. Druck von R. Nischkowsky, Breslau.

WOJTUŃ B., MATUŁA J. 2000. Nowe stanowisko Rubus chamaemorus (Rosaceae) w polskiej części Karkonoszy [A new locality of Rubus chamaemorus (Rosaceae) with the Polish part of the Karkonosze Mts (Sudety Mts)]. Fragm. Flor. Geobot. Polonica 7: 364-365. (in Polish with English summary)

ZARZYCKI K., TRZCIŃSKA-TACIK H., RÓŻAŃSKI W., SZELĄG Z., WOŁEK J., KORZENIAK U. 2002. Ecological indicator values of vascular plants of Poland. Biodiversity of Poland, vol. 2, pp. 1-183. W. Szafer Institute of Botany, Polish Academy of Sciences. Kraków.

ZARZYCKI K., SZELĄG Z. 1992. Czerwona lista roślin naczyniowych zagrożonych w Polsce [Red list of threatened vascular plants in Poland]. In: K. Zarzycki, W. Wojewoda, Z. Heinrich (eds). Lista roślin zagrożonych z Polsce [List of threatened vascular plants in Poland]. Ed. 2, pp. 87-97. W. Szafer Institute of Botany, Polish Academy of Sciences, Kraków. (in Polish with English summary) 